South Africa and the Aftermath of Portugal's 'Exemplary' Decolonization: The Security Dimension

Author(s): Filipe Ribeiro de Meneses and Robert McNamara

Source: Portuguese Studies, Vol. 29, No. 2 (2013), pp. 227-250

Published by: Modern Humanities Research Association

Stable URL: https://www.jstor.org/stable/10.5699/portstudies.29.2.0227

JSTOR is a not-for-profit service that helps scholars, researchers, and students discover, use, and build upon a wide range of content in a trusted digital archive. We use information technology and tools to increase productivity and facilitate new forms of scholarship. For more information about JSTOR, please contact support@jstor.org

Your use of the JSTOR archive indicates your acceptance of the Terms \& Conditions of Use, available at https://about.jstor.org/terms 


\title{
South Africa and the Aftermath of Portugal's 'Exemplary' Decolonization: The Security Dimension
}

\author{
Filipe Ribeiro de Meneses and Robert McNamara
}

\author{
UNI-Maynooth
}

\begin{abstract}
Allister Sparks, in his seminal study of Apartheid, The Mind of South Africa, writes: 'though it occurred five thousand miles away among another people in another continent, in South Africa the Portuguese Revolution was an event of catalytic importance that changed the whole directional flow of public affairs'. 25 April 1974 was, for Sparks, a 'simultaneous turning point at which the Afrikaner revolution created and entered a phase of crisis and decline, and at which the black revolution began its rise.' The end of the Salazar/Caetano New State, and the hurried decolonization that followed, would indeed alter dramatically the balance of power in southern Africa, but it took the decisionmakers in Pretoria time to realize this - time that they did not, in fact, possess. The purpose of this article is to examine the reaction of those decision-makers to the events in Lisbon and, of course, in Mozambique and Angola, and to show that there was no coordinated, over-arching response: like other regional powers, and even the superpowers, South Africa was caught off guard by the 'Carnation Revolution', and struggled, as the pace of developments increased, to identify precisely where its national interests lay, being hampered in its attempts by too great a confidence in its ability to survive the ongoing transformation of the region, and by internal power struggles.
\end{abstract}

\section{Before the Revolution}

By the late 196os, South Africa had become firmly convinced of the necessity of preserving Portugal's rule in the latter's African territories. Isolationist premier Henrik Verwoerd had been replaced by John Vorster, who encouraged increasing cooperation between both the South African Defence Forces (SADF) and the powerful intelligence services under the direction of Henrik van den Bergh and their Portuguese and Rhodesian counterparts. ${ }^{2}$ Military cooperation

\footnotetext{
1 Allister Sparks, The Mind of South Africa (Johannesburg: Jonathan Ball, 2003), p. 303.

2 See for instance P. Correia, and G. Verhoef, 'Portugal and South Africa: Close Allies or Unwilling Partners in Southern Africa during the Cold War?', Scientia Militaria: South African Journal of Military Studies, 37.1 (2009) <http://ajol.info/index.php/smsajms/article/view/48731>. A recent treatment

Portuguese Studies vol. 29 no. 2 (2013), 227-50

(C) Modern Humanities Research Association 2013
} 
had culminated in October 1970 in Exercise ALCORA, which provided for increasingly close staff talks between the militaries of the three countries and the development of which accelerated considerably from the autumn of 1973 until April $1974 .^{3}$ In this period South Africa and Rhodesia sought ever closer military ties, and this desire sparked off a high-level disagreement within Portuguese military circles regarding Pretoria's proposed 'total strategy'. Nonetheless, as Jamie Miller has recently observed, under 'Operation Cadiz', launched in September 1973, P. W. Botha, the South African Defence Minister, committed South Africa to bankrolling Portuguese counter-insurgency to the tune of R150 million over five years. Thanks to these funds significant purchases - including of French-designed Crotale surface-to-air missiles - were made by the Portuguese in the months preceding the April 1974 revolution. ${ }^{6}$

Despite the coming into being of Exercise ALCORA, and the countless threat assessments it produced, there is only scant evidence that South Africa, and especially its intelligence services, anticipated the revolution of 25 April 1974, carried out by the mid-ranking officers of the Armed Forces Movement (MFA). In some respects this reflected the inadequacies of BOSS, headed by General H. J. van den Bergh, 'probably the strongest man in the country after Vorster', 7 wich had increasingly colonized the intelligence field, much to the chagrin of the Directorate of Military Intelligence of the SADF. However, there is little evidence extant that the Defence Forces' military and naval attaché, their eyes and ears in Lisbon, was any better informed. On the Rhodesian side, Ken Flower, head of the Central Intelligence Organization (CIO), claimed to be sceptical about the long-term survival of the Portuguese empire in Africa,

of some of these issues can also be found in Jamie Miller 'Things Fall Apart: South Africa and the Collapse of the Portuguese Empire, 1973-74', Cold War History, 12.2 (2012), 183-204.

3 On Exercise ALCORA, see Filipe Ribeiro de Meneses and Robert McNamara, 'The Last Throw of the Dice: Portugal, Rhodesia and South Africa, 1970-1974', Portuguese Studies, 28.2 (2012), 201-15, as well as two forthcoming articles in International History Review: 'The Origins of Exercise ALCORA, 1960-1971', and 'Exercise ALCORA: Expansion and Demise, 1971-1974'. ALCORA is inserted into a wider Portuguese diplomatic strategy in Luís Barroso, Salazar, Caetano e o Reduto Branco: a manobra político-diplomática de Portugal na África Austral (1951-1974) (Lisbon: IESM/Fronteira do Caos, 2012). 4 The secret reservations of General Costa Gomes, Chief of Staff of the Armed Forces and second post-revolution President of the Republic, can be seen for instance in Paço de Arcos, Arquivo da Defesa Nacional, Secretariado Geral da Defesa Nacional, Caixa 7624, 'Constituição de Forças de Reserva e Estratégicas ALCORA', 25 October 1973. Given the importance of the commitments being entered into with South Africa and Rhodesia at the time, it is difficult not to link these commitments to the publication, by General António de Spínola (Costa Gomes' second-in-command and the first postrevolution President of the Republic), of his famous book Portugal e o Futuro (Lisbon: Arcádia, 1974), which argued that the war could not be brought to an end by military means.

5 Miller, 'Things Fall Apart', p. 190.

6 ADNPdeA, SGDN, Série 25, Caixa 57, 'Acordo do empréstimo de 150 milhões de rands firmado com a RAS', 18 September 1975 . The deal was alluded to in very vague terms by Silva Cunha in his interview with José Freire Antunes (January 1995), and published in the latter's A Guerra de África, 1961-1974, 2 vols (Lisbon: Temas e Debates, 1996), I, 333-42.

7 Foreign Relations of the United States, 1969-1976, vol. xxviII, Southern Africa (Washington, DC: Government Printing office, 2011), Doc. 10, Intelligence Note From the Director of the Bureau of Intelligence and Research (Hughes) to Secretary of State, Rogers, 24 June 1969. 
and was despondent when he visited Portugal just before the coup - but this prescience was only made public in his memoirs, published long after the fact. $^{8}$

\section{February 1974: A Snapshot of the Threat to the 'White Redoubt'}

ALCORA's Intelligence Sub-Committee issued a report on the threat to whiterule southern Africa dated 15 February 1974, which serves to demonstrate the dangers faced by the ALCORA territories in the short, medium and long term, as perceived by Portugal, Rhodesia and South Africa. ${ }^{9}$ The report concentrated on the African liberation movements, invariably referred to as 'terrorists', the Organization of African Unity (OAU), the Communist Bloc and the West. Terrorism and subversion, backed by the OAU, was seen to have achieved 'significant successes' in Rhodesia and Mozambique during $1973 .{ }^{10}$ The embargo imposed during the October war in the Middle East by the oilproducing Arab states, it was noted, had 'already had a restricting effect on the military capabilities of ALCORA'.11 The terrorist threat to Rhodesia was likely to grow, and encompass three distinct fronts: across the Zambezi river from Zambia by ZAPU; from the Tete district of Mozambique, now partially controlled by FRELIMO, by ZANU; and from an increasingly hostile Botswana. Even South Africa, despite its cordon sanitaire of Rhodesia and the Portuguese territories, might be dragged into the firing line, due to the 'more militant attitude among the Bantu population', and the growing likelihood of Botswana becoming 'a relatively safe base for infiltrations to the RSA (Republic of South Africa) and SWA (South West Africa) in the medium term'. FRELIMO's progress could also lead to South African African National Congress (SAANC) terrorist activities in the Northern Transvaal. Angola was likely to see an extension of terrorism as well, and the possibility of armed intervention by neighbouring states, presumably Zaire, in the oil-rich Cabinda enclave could not be ruled out. Mozambique, however, was estimated to be the target selected by the OAU 'among the territories of ALCORA as its primary objective with the intention to deny the Portuguese control of the territory. For this purpose it is possible that the OAU will exert pressure on FRELIMO to intensify its action and on the hostile neighbour countries to grant great support to that movement. ${ }^{, 12}$ While there was no immediate threat of large-scale OAU military intervention, as it would be hampered by inter-state rivalries, conflicting

8 Ken Flower, Serving Secretly: An Intelligence Chief on Record. Rhodesia into Zimbabwe 1964 to 1981 (London: John Murray, 1987), p. 117.

9 Pretoria, South African National Defence Archive, INT/2 ALCORA 13 'Exercise ALCORA: An Assessment of the Threat to the ALCORA Territories in the Short, Medium and Long Terms 15 February 1974'.

$10 \quad$ Ibid, paragraph 5.

11 Ibid, paragraph 7.

12 Ibid, paragraph, 11. 
interests, internal security demands, and cost, the completion of the TanzaniaZambia (TANZAM) railway might 'make support of such force operating against the ALCORA Territories more feasible. ${ }^{13}$ The threat from the Soviet Union and China could also be expected to grow. All this would take place in a world where the Western Powers (among which more left-wing governments could be expected) were 'likely to act with indifference bordering on timidity so far as support for ALCORA is concerned, despite their apparent revulsion at the use of force for political purposes by some sections of the Western World'. ${ }^{14}$ In other words, while the external situation was growing bleaker for ALCORA, there was no suggestion of imminent collapse from within, and it was surely ALCORA's greatest failing that, in spite of the growing resources put into institutional liaison between the militaries of the three countries, South Africa and Rhodesia had no advance warning of the military coup in Lisbon.

\section{A Catastrophic Intelligence Failure}

South African diplomats and intelligence officials certainly knew trouble was brewing in Portugal in early 1974. On 3 January Ambassador Montgomery reported rumours of a right-wing coup involving, among others, General Kaúlza da Arriaga, a former Commander-in-Chief in Mozambique. ${ }^{15}$ The first concrete sign that the regime of Marcello Caetano was under threat came with the publication of General António de Spínola's book Portugal e o Futuro, which started from the premise that there was no military solution to Portugal's wars in Africa, and proposed a much looser, federal, relationship with the colonies. After some hesitation in government circles, Spínola and Costa Gomes, the two highest-ranking officers in the country's armed forces, were dismissed after refusing to pay homage to the government at a hastily improvised ceremony (Costa Gomes having authorized the publication of the work). BOSS sent the Ministry of Foreign Affairs an intelligence briefing on 20 March 1974 for comment. It concluded that Portugal e o Futuro was an attempt to propose an Algeria-style Gaullist solution to the colonial wars. However, Caetano's speech of 16 February had rejected Spínola's federal solution, since Portuguese settlers and economic interests would not be respected by the independence movements. The brief speculated that Caetano might have encouraged the publication as a kite-flying exercise, only to be forced, by the reaction of the right-wing ultras, to remove Spínola and Costa Gomes. In any case, the danger had passed. ${ }^{16}$ This completely contradicts the later claim of Eschel Rhoodie, the Secretary of the

13 Ibid, paragraph 12.

14 Ibid, paragraph, 16.

15 South African Department of Foreign Affairs, Pretoria, 1-14-1 Vol. 9 Portugal Political Situation and Developments 4.10.72 to 21.5.74, Letter, South African Ambassador in Lisbon to the Secretary for Foreign Affairs, Lisbon, 3 January 1974..

16 SADFAP 1-14-1 Vol. 9 Portugal Political Situation and Developments 4.10.72 to 21.5.74, Die Sekretaris Van Buitelandse. Portugal: Magstryd In Politieke Kringe, 20 March 1974. 
Department of Information, that Van den Bergh had predicted the coup a year before and had informed the CIA, which had sent him a letter of congratulation for being the only intelligence organization to anticipate it. ${ }^{17}$ Moreover, it does not tally with the other BOSS documents that occasionally turn up in the files of the Department of Foreign Affairs. Immediately after the revolution, for example, BOSS issued a memorandum which reflected a relatively sanguine attitude to the revolution. Its key conclusion was that:

Despite Spínola's strong commitment to a political solution, a continued Portuguese military presence in Africa seems inevitable for some time. If Lisbon does not move in a reasonable length of time, the rebels could attempt to step up their activities against the territories, which are not capable of maintaining their own defence without substantial help from Lisbon. [...] [Guinea] is an economic liability with no hope of producing the immediate and long term economic riches of Angola and Mozambique. Lisbon is unlikely to risk the loss of Angola and Mozambique, however, and the insurgents there are unlikely to accept the type of federation presently being considered by Spínola. ${ }^{18}$

Admittedly, there was a lot of Portuguese reassurance being given to the South Africans about the continued commitment to a presence in Africa in the aftermath of the coup. The Portuguese Ambassador in Washington informed his South African counterpart that, while a revolution was indeed taking place, the new regime was led by sober men. João Hall Themido explained, mistakenly, that General Spínola, now President of the Republic, was both the leader and the catalyst of the revolution (in fact, he turned out to be a relatively powerless figurehead, but few realized this at the time); and whilst he could give little information about Africa beyond what had been in the press, he believed that the regime was sincere when it spoke of a 'Lusitanian community'. Moreover, it was his impression 'that the chances of orderly devolution in Angola - and even in Mozambique - were "fair". He emphasized that it was not policy to capitulate precipitately in Africa. ${ }^{\text {'19 }}$ The South African Ambassador in Paris, in a despatch in June 1974, mentioned that the French government 'was like ourselves in South Africa, somewhat taken by surprise at the sudden change of government in Portugal in April. The conclusion was that the move had been well-planned and the coup d'état executed in great secrecy. ${ }^{20}$ In other words, the situation in Lisbon was nearly impossible to read. But this was not necessarily the case. A State Department official, Ellwood Rabenold Jr, presciently referred

17 Interview with Rhoodie cited in James Saunders, Apartheid's Friends: The Rise and Fall of South Africa's Secret Service (London: John Murray, 2006), pp. 50-51.

18 SADFAP, 1-14-1 Vol. 10, Portugal Political Situation 27.5.74 to 10.9.74, BOSS to Secretary for Foreign Affairs, 6 June 1974, enclosing memo 'Estimate of Portuguese Situation for Mike Glendenhuys', 1 May 1974.

19 SADFAP 1-14-1 Vol. 10, Ambassador Washington to Secretary for Foreign Affairs, Pretoria, 4 June 1974.

${ }_{20}$ SADFAP 1-14-9 Vol. 5 Portugal Foreign Policy and Relations 9.11.72 to 30.6.75, Ambassador Paris to Secretary for Foreign Affairs, Pretoria, 14 June 1974. 
to conflicting views between those such as Spínola, who favoured a federal plan, and others, such as the new Foreign Minister, Mário Soares, whose views seemed to align more with the liberation movements. ${ }^{21}$

South Africa was soon faced with a major new strategic dilemma on its northern frontiers as it gradually became clear that Spínola and the National Salvation Junta were not free to implement their African policies. Lisbon was coming under intense international pressure to move to a straightforward handing of power to the liberation movements, while radical elements in Portugal, within and without the MFA, saw this kind of 'exemplary' decolonization as intertwined with their domestic agenda of establishing an avowedly revolutionary state. Most importantly, however, the Portuguese army had lost the will to fight, thus destroying any possibility of a gradual handover of power. For some months, however, the messages emanating from Portugal remained confused. General Costa Gomes, restored by Spínola to the position of Chief of Staff of the Armed Forces, visited Africa in May, and rejected the idea of immediate independence. While offering an olive branch of partnership to the liberation movements, he also claimed that Portugal would fight on to safeguard Mozambique if the rebels rejected his offer of talks. ${ }^{22}$ This turned out to be an empty boast. At roughly the same time, moreover, Jorge Jardim, the Portuguese settler leader in Mozambique and Salazar's one-time enforcer in Africa, was in Lisbon. The correspondence in the South African files suggests that he was attempting to forge links with Pretoria and that General de Toit, the head of Military Intelligence, showed some interest. ${ }^{23}$ Jardim's activities and

21 A United States Bureau of Intelligence and Research memorandum speculated that South Africa might intervene militarily in southern Mozambique if the Portuguese withdrew precipitately. South Africa, it was felt, would tell Washington that white-rule southern Africa had to continue 'as an anti-Communist Bastion'. The memorandum rejected this argument in advance, pointing out that 'there is an underlying instability in southern Africa stemming from minority racial rule. The latest developments in Lisbon should make this more rather than less apparent as time goes on.' Department of State Central Files, 1973-76, Record Group 59, 040027Z, May 74, 'INR Assessment of African Repercussions of the Portuguese Coup', 30 April 1974.

${ }_{22}$ South African Institute of Race Relations, A Survey of Race Relations in South Africa, 1974 (Johannesburg: South African Institute of Race Relations, 1975), p. 104.

${ }_{23}$ SADFAP 1-113-3 Relations with Mozambique 20.3.65 to 26.5.82, Ambassador Lisbon to Secretary Foreign Affairs, 29 May 1974. Jorge Jardim, a former junior minister in the 1950s, and Salazar's special agent in Africa throughout the 1960s, was by now established as a major political and economic force in Mozambique. He also provided an important personal link to Malawi's President, Hastings Kamuzu Banda, who named him Malawi's Consul at Beira. Jardim was the most prominent member of a political current, to which his newspapers in the city of Beira gave great coverage, which argued that FRELIMO could be persuaded to share power with hastily assembled political parties and settler groups. Jardim had, even before the revolution, convinced President Kenneth Kaunda of Zambia of the merits of a similar programme, which he described as the 'taming' of FRELIMO. See his memoirs, Moçambique, terra queimada (Lisbon: Intervenção, 1976). An account of Jardim's action-packed life is provided by José Freire Antunes in Jorge Jardim: agente secreto (Venda Nova: Bertrand, 1996). It is believed that some white settlers from Mozambique with links to Jardim, including future RENAMO leader Orlando Cristina, supplied the Rhodesians with Portuguese police files from which they could begin to build up a picture of likely recruits for that opposition organization. On this see Tom Young, 'The MNR/Renamo: External and Internal Dynamics', African Affairs: The Journal of the Royal African Society, 89.357 (1990), 491-509 (p. 494). 
his past fed Portuguese suspicions that he was a possible leader of a unilateral declaration of independence by settlers, something he denied. ${ }^{24}$ This was causing the South African Ambassador in Lisbon some concern. When Jardim finally left Lisbon for Blantyre, Ambassador Montgomery gave a great sigh of relief. ${ }^{25}$ Meanwhile, the South African Ambassador in Paris reported in early June 1974 that Mário Soares' first meeting with Samora Machel of FRELIMO had not gone well, as the liberation movement only wished 'to discuss the modalities of a transfer of power to a FRELIMO government.' According to the report, this 'was unacceptable to the Portuguese government as a whole, although some of the politicians in the government adopt a softer line on the matter.' ${ }^{26}$

South Africa's ability to read the situation clearly was further muddled by the fact that Exercise ALCORA continued into the autumn of 1974. An ALCORA Top Level Committee (ATLC) meeting was held at the end of June in Pretoria. Remarkably, the planning to give ALCORA greater solidity through the establishment of the Permanent ALCORA Planning Organization (PAPO) continued, and the meeting went through a considerable agenda, including weapons procurement, intelligence matters and future developments. ${ }^{27}$ However, it was acknowledged in the report by Major General Clifton, Director General Special Plans of PAPO, that morale and productivity had suffered as a result of the Portuguese coup. ${ }^{28}$ It was only in July that the political balance of power in Lisbon became clear to the naked eye. That month, the first post-revolution government fell, and its replacement, led by Colonel Vasco Gonçalves, represented a significant shift to the left, with the MFA clearly in the ascendancy and Spínola, correspondingly, in retreat. This, allied to the breakdown in the Portuguese army's discipline, meant that the liberation movements in Guinea and Mozambique could ignore Spínola's calls for referendums or pre-independence elections. The very speed of the ensuing Portuguese collapse at the negotiating table meant that one obvious alternative for South African and Rhodesian strategy, a settler-led counter coup, with or without Jardim, never had time to organize itself properly. On 7 September 1974, when the Lusaka Accord was announced, naming 25 June 1975 as Mozambique's independence day, white settlers in Lourenço Marques and Beira attempted to rise against it. They attacked black neighbourhoods, freed

\footnotetext{
24 See SADFAP 1-14-3 Vol. 1, Portugal relations with SA 15.7.64-13.8.82, South African Embassy Lilongwe to Secretary Foreign Affairs, Pretoria, 5 Aug 1974.

25 SADFAP 1-113-3 Relations with Mozambique 20 Mar 1965 to 26 May 1982, Ambassador Lisbon to Secretary Foreign Affairs, 11 June 1974.

26 SADFAP 1-14-9 Vol. 5 Portugal Foreign Policy and Relations 9.11.72 to 30 .6.75, Ambassador Paris to Secretary for Foreign Affairs, Pretoria, 14 June 1974. Soares, of course, was one of those politicians, but for the time being he respected the wishes of President Spínola, whose instructions he was following. The same cannot be said for his fellow negotiator and future revolutionary pin-up Otelo Saraiva de Carvalho, who at one point in the talks sided openly with FRELIMO.

27 SANDFAP, ALCORA 6, Minutes of 7th ATLC Meeting, Pretoria, 24-28 June 1974.

28 Ibid, Annex 1, Report by Director General Special Plans.
} 
imprisoned DGS (secret police) agents, seized the airport and radio stations, and appealed for help among all FRELIMO's opponents, in Mozambique and abroad, but with no success. ${ }^{29}$ South Africa appears not to have played any role in the outbreak, although many of those who took part gathered around the South African consulate shouting 'Viva a África do Sul'. Unimpressed, the consul-general in Lourenço Marques suggested that South Africa could gain considerable advantage from FRELIMO's lack of support from different ethnic groups 'provided that we are seen to remain absolutely neutral so that we do not engender animosity from any quarter in the country. ${ }^{30}$ Vorster, in an interview with Newsweek, was dismissive of fears of a black government in Mozambique. He was equally dismissive of Portugal's colonial model:

After all events in Mozambique, Angola and Guinea-Bissau have proved our policy of separate development right. The root of the trouble in all these territories was that the Portuguese policy was one of assimilation - which was a negation of the nationhood of their people [...] if relations were that good why did they fight each other so much? Why are they still fighting? Why are the whites running out of Mozambique and Angola? ${ }^{31}$

This arrogance, this sense of being somehow above the fray and impervious to the great currents that had just engulfed the Portuguese colonies, and would soon do the same for Rhodesia, was characteristic of South Africa's political masters. Nevertheless the thought of FRELIMO - a Marxist liberation movement - coming to power must have given them cause for concern. FRELIMO's leadership was on the record as saying that it would not cooperate with South Africa, even to the extent of denying it electricity from the soon-to-becompleted Cabora Bassa dam. ${ }^{32}$ The ALCORA Intelligence documents referred to above demonstrate that the South African military feared that Mozambique might become a base for the SAANC from which to attack into Northern Transvaal. ${ }^{33}$ However, South Africa showed itself willing, at least initially, to follow a conciliatory path; perhaps its leaders simply could not believe that a Mozambican government, whatever its political creed, would dare to act against Pretoria, given the enormous dependence of the Mozambican economy on South African goodwill. Indeed, in May 1974, just a month after the Lisbon revolution, Vorster stated, with regard to Mozambique, that he was not worried about 'the colour of the people concerned'; he pledged non-interference in Mozambican affairs, and said that South Africa was interested solely in stable government

29 Malyn Newitt, A History of Mozambique (London: Hurst \& Company, 1995), pp. 538-40.

30 SADFAP 1-113-3 Mozambique Relations with SA 20.3.65 to 26.5.82, Consul Lourenço Marques to Secretary Foreign Affairs, 16 September 1974 and SADFAP 1-113-3 Vol. 6A Mozambique relations with S.A. 10.12.73 to 28.8.74, Consul, Lourenço Marques to Secretary Foreign Affairs, 19 October 1974.

${ }^{31}$ Newsweek, 16 September 1974.

32 According to journalist Ray Vicker, Cabora Bassa represented a 450 million dollar investment, with most of the money being South African in origin. Wall Street Journal, 7 August 1972.

33 Mário Joaquim Azevedo, 'A Sober Commitment to Liberation? Mozambique and South Africa, 1974-1979', African Affairs, 79.317 (1980), 567-84 (p. 568). See also 'An Assessment of the Threat to the ALCORA Territories', 15 February 1974, para. 11. 
there. ${ }^{34}$ Ian Smith, the Prime Minister of Rhodesia, whose sanctions-busting strategy was deeply dependent on a friendly Mozambique, discovered that Vorster really meant these words when the two met in July. Smith explained to Vorster that he had contact with 'powerful forces in Mozambique' who had a plan to take over Mozambique south of the Zambezi and form a kind of Federation with South Africa and Rhodesia. This would allow Rhodesia to continue to use the port facilities at Beira. Vorster initially showed interest in the plan and said he would consider it and contact Smith on the matter, but proved slow to respond. Some months later, he rejected the idea outright, having 'come to the conclusion that there would be an unfavourable reaction from the rest of the world, and that therefore they could not support it. ${ }^{\text {'35 While }}$ Smith is imprecise on the date of the reply, it would appear to have been after 7 September 1974, the date of the abortive settler uprising in Mozambique which had cost some 115 lives. $^{36}$

Ian Smith and other observers suggest that at this point South Africa had already committed itself to a policy of détente with Black Africa, which was only officially promulgated by Vorster in the South African parliament in October 1974. However, Vorster remained committed to keeping a South African Police unit in Rhodesia, arguing that it was there to prevent a terrorist threat to South Africa developing. ${ }^{37}$ And there remain persistent rumours that Defence Minister P. W. Botha and the SADF were on the verge of intervening in Mozambique around this time, only to be thwarted by BOSS agents. ${ }^{38}$ BOSS tended to provide the like-minded Department of Foreign Affairs with intelligence material that emphasized the reasonableness of FRELIMO and its leader, Samora Machel. ${ }^{39}$ In any case, FRELIMO had rapidly cooled its anti-South Africa rhetoric. In September 1974, the newly installed Prime Minister, Joaquim Chissano, made it clear that FRELIMO would not interfere with Rhodesia or South Africa and would not be a 'saviour' or 'messiah' for either country's majority African populations, who would have to resolve their respective problems on their own..$^{40}$

Early in September 1974, Ken Flower, General van den Bergh and Brand Fourie, Secretary of the Department of Foreign Affairs, were in Lisbon for meetings with the Portuguese. There, António de Almeida Santos, the Minister

34 Quoted in John Barratt, 'Detente in Southern Africa', The World Today: Chatham House Review, 31.3 (1975), 120-30 (p. 124). See also Vorster on 1 August 1974 in Parliament, Hansard 4 Cols, 1857-6o.

35 Ian Smith, Bitter Harvest: The Great Betrayal and the Dreadful Aftermath (London: John Blake, 1997), pp. 160-61.

36 A Survey of Race Relations in South Africa, 1974, p. 111.

37 Rand Daily Mail, 6 October 1974.

38 Dan O'Meara, Forty Lost Years: The Apartheid State and the Politics of the National Party (Athens: Ohio University Press, 1996), p. 219.

39 See for instance SADFAP 1-113-3 Vol. 6B, Mozambique Relations with SA 3.9.74 to 24.10.74, BOSS Memo to Secretary Foreign Affairs, 24 October 1974, containing an astonishingly detailed report on a meeting of British Officials and Ministers.

40 Azevedo, 'A Sober Commitment to Liberation?', p. 580. 
for Inter-Territorial Coordination, outlined the likely agreement between Portugal and FRELIMO that was to be the basis of the Lusaka Accords. General van den Bergh gave an absolute assurance that South Africa would not allow mercenary forces to be organized in South Africa against Angola or Mozambique and that Jorge Jardim had been warned not to engage in such activities. ${ }^{41}$ Flower stayed longest in the Portuguese capital and looked up some of his old contacts. These, contrary to the assurances given earlier by Foreign Minister Mário Soares, suggested that FRELIMO's word was worth nothing. And while there was talk of a potential right-wing coup in Portugal, which might influence the course of events in Angola, it seemed as if the situation in Mozambique had developed to a point where there was no turning back. ${ }^{42}$ Flower was rather more forthcoming in his memoirs about his knowledge of what was going on in Lisbon, referring to his direct participation in the plotting of a countercoup which involved Spínola himself. ${ }^{43}$ This, presumably, was Spínola's failed attempt to rally the 'silent majority' to his side, later that month, which ended not with a defeat for the left, but rather the President's resignation, and led to the strengthening of the MFA's hold over the institutions of the Portuguese state.

\section{Picking up the Pieces after Mozambique}

Exercise ALCORA ended at a meeting on 14 and 15 October 1974 in Lisbon. General J. A. Pinheiro, the assistant to the Chief of Staff of the Armed Forces (a position which General Costa Gomes held on to, despite his recent acceptance of the Presidency of the Republic), addressed the meeting and made clear that ALCORA was over, due to the recent Lusaka agreements with FRELIMO. Not even the 'hot-pursuit' operations so beloved of Rhodesian forces would be allowed any longer. The codename ALCORA was to be dropped and PAPO would cease to exist on 31 October 1974. Despite the ending of what had become to all intents and purposes a military alliance, the meeting concluded on a friendly note, without recrimination. ${ }^{44}$ Whether as a direct or an indirect result of the end of the ALCORA strategy, which had subcontracted out the defence of South Africa to the Portuguese military, Vorster's government stepped up its moves towards détente with the rest of Africa. This seems to have informed Pretoria's policy on Mozambique and its decision from October 1974 to pursue a policy of pressurizing the Rhodesian government to come to terms with African nationalists. By the end of the year, South Africa had, with the cooperation of Zambia in particular, negotiated a very shaky ceasefire between the Rhodesian

41 SADFAP 1-14-3 Vol. 1 Portugal Relations with SA, 15.7.64 to 13.8.82, Meeting in Lisbon, 2 September 1974, between Dr Almeida Santos, B. G. Fourie and General van den Bergh.

${ }^{42}$ SADFAP 1-14-1 Portugal Political situation 27.2.70 to 3.5.84, Representative Salisbury to Secretary for Foreign Affairs, 18 September 1974.

43 Flower, Serving Secretly, pp. 144-45.

44 SANDFAP, ALCORA 7, Minutes of the 8th ATLC Meeting, Lisbon 14-15 October 1974. 
government and the liberation movements which opposed it. While various negotiations over the next two years - Victoria Falls (August 1975), the Kissinger Plan (September 1976), and the Geneva conference (December 1976) ${ }^{45}$ - ended in failure, primarily on the rocks of the Rhodesian Prime Minister's intransigence and the serious splits in the liberation movements, they forestalled the drift to full-scale war in Rhodesia for nearly two years.

In Pretoria, however, not everyone was convinced of the merits of détente. Meeting in February and September 1975 under the auspices of a successor liaison group to ALCORA, Rhodesian military and SADF officers produced a document on the 'Military Threat to the Republic of South Africa and Rhodesia'. ${ }^{46}$ Reiterating that the threat stemmed from 'black political aspirations' supported by the OAU, the Communist Bloc and certain Western countries, it concluded that the surrender of effective Portuguese control in Mozambique had added momentum to the dangers facing both countries and contributed to 'an aggressive and uncompromising attitude towards the Republic of South Africa (RSA) and Rhodesia [...] The white-controlled states of southern Africa face the present developing threat in an atmosphere of increasing hostility and isolation.' It was noted that the OAU, which had met in Dar es Salaam in April 1975, had as its 'ultimate aim the total elimination of white rule in southern Africa.' There was also concern about President Amin of Uganda, the then Chairman of the OAU, and his attempt to revive the concept of an all-Africa Army, though it was noted that certain elements in the OAU had reservations about Amin's 'reputation and unpredictability'. While President Kaunda of Zambia was in favour of détente with South Africa, he had made clear that any collapse in the negotiations between the African National Council and the Rhodesian government not attributable to intransigence on the part of the ANC would lead to Zambia supporting whatever course the ANC chose to use to attain majority rule. ${ }^{47}$ Meanwhile, it was concluded that Mozambique's precarious economy precluded any 'drastic political or economic steps against Rhodesia or the RSA', although its support for ZANU was likely to continue and the SAANC was likely to be granted facilities in the near future, if only on a low-profile basis. The report concluded that the Movimento Popular de Libertação de Angola (MPLA) was best placed to succeed in taking power in Angola. The strategy of détente was useful in preventing revolutionary aims and had led to some new political thinking in some African states 'which had curbed the activities of terrorist organisations.' Conversely, however, it had

45 See for instance, R. W. Johnson, How long will South Africa survive? (London: Macmillan, 1977), pp. 1-16; Sue Onslow, "We must gain time": South Africa, Rhodesia and the Kissinger Initiative of 1976', South African Historical Journal, 56 (2006), 123-53 and Ian Smith, Bitter Harvest, pp. 160-222. There is a huge volume of correspondence on these events in the Ian Smith Papers at Cory Historical Library, Rhodes University, Grahamstown, South Africa in Box 4-0oo6 M (Official Communications with South Africa, Volumes 1-7).

${ }_{46}$ SANDFAP, ALCORA 13, 'The Military Threat to the Republic of South Africa and Rhodesia', September 1975 .

47 'The Military Threat to the Republic of South Africa and Rhodesia', 24 September 1975, paragraph 7. 
'adversely affected the counter terrorist campaign in Rhodesia'. ${ }^{48}$ The instability engendered by the collapse of Portuguese power, 'especially the instability in Angola and Mozambique', had 'resulted in Communist countries and Communist organizations intensifying their efforts to exploit and manipulate the conflict situation as whole, to gain initiative and influence. ${ }^{39}$

On 21 October 1975, a Portuguese diplomat based at the Permanent Representation to the United Nations reported that Portugal had no intention of handing over power solely to the MPLA. This official also suggested that Mozambique had plans to initiate discussions with South Africa regarding the establishment of diplomatic relations with Pretoria, as it was feeling the economic pinch from the loss of tourist revenue. ${ }^{50}$ At least in the immediate aftermath of Mozambique's independence, South Africa appeared to have reached a modus vivendi with its newly independent neighbour. However, this would change. FRELIMO's escalating support for ZANU in its war against Rhodesia, particularly after the failure of Vorster's détente initiative and the Kissinger Plan by the end of 1976, would see Mozambique become the major target of Rhodesian retaliation. This included a series of military assaults against ZANU-controlled guerrilla and refugee camps and the aiding and abetting of the Mozambique National Resistance (RENAMO), which waged a terrifyingly brutal war against FRELIMO and the civilian population of Mozambique. The end of Rhodesia in early 1980 would see South Africa take over the aiding of RENAMO from the Rhodesian CIO 'lock, stock and barrel' in order to pressure Mozambique not to back any of the South African liberation movements. ${ }^{51}$ South African agents also carried out a series of raids and bombings on ANC activists. The Nkomati Accord (1984) forced FRELIMO to shut the ANC office in Mozambique in return for a South African pledge to stop support for RENAMO. However, relations remained strained and when President Samora Machel was killed in a plane crash in South Africa, in 1986, many believed it was the work of South African agents. ${ }^{52}$ Still, South Africa had at least avoided being dragged into conflict in Mozambique in 1974-75. The same was not true of Portugal's other major colony in southern Africa, Angola.

\section{The Intervention in Angola}

The intervention in Angola was, according to Colin Legum, an exiled South African journalist, 'possibly the most traumatic event in South Africa's history since the Anglo-Boer war at the turn of the century. ${ }^{53}$ South African troops had

$48 \quad$ Ibid, paragraph 11.

49 Ibid, paragraph 12.

50 SADFAP 1-14-1 Vol. 12 Portugal Political Situation and Developments 6.5.75 to 31.10.1975, SA mission New York, 23 October 1975.

51 Flower, Serving Secretly, p. 262.

52 See Saunders, Apartheid's Friends, pp. 218-21.

53 Colin Legum and Tony Hodges, After Angola: The War over Southern Africa (London: Holmes \& Meier, 1976), p. 35. 
been committed to a conflict in southern Africa and some of its soldiers had been taken prisoner. However, South African strategy in Angola developed very slowly and with considerable reluctance. While, on the one hand, there was less of an economic imperative to reach an understanding with whoever emerged triumphant in Angola, on the other, the situation in Angola was very different to the one which had played itself out so quickly in Mozambique. Spínola had been able to retain a say in Angolan affairs until September 1974, trying to preserve, there at least, his vision of a Lusitanian community; the much larger white settler population seemed determined to stay in the territory, and capable of doing so; and the presence of three liberation movements, each with its own international connections, contributed massively to this incredibly complex situation, fraught with dangers but also with opportunities. The consul-general in Luanda, Emmett 'Mike' Malone, differentiated little between the three competing liberation movements in his reportage. He noted, for instance, that the Frente Nacional de Libertação de Angola (FNLA) Minister of the Interior in the transitional government that was established by the January 1975 Alvor accords had issued a bellicose statement claiming the SADF was in the process of seeking a pretext for invading Angola. ${ }^{54}$ All three movements seemed to be responsible, he explained, for the chaos that engulfed Angola in general, and Luanda in particular, as Portuguese power disintegrated throughout 1975, undermined by domestic politics, the army's state of mind, and international pressure. This included shooting at South African Airways flights, which ended their service in Luanda, an important stopover on the way to Europe and the Americas. ${ }^{55}$ As late as June 1975, the United States did not see any preparations for South African intervention. ${ }^{56}$

South Africa's invasion of Angola has generated a considerable literature. ${ }^{57}$

54 SADFAP 1-22-3 Vol. 5 Angola Relations with SA, 5.3.75. to 25.7.75, Consul-General Luanda to Secretary Foreign Affairs, 18 April 1975 and 23 April 1975. The Minister for the Interior (FNLA) repeated such accusations in July: see Secretary for Foreign Affairs to SA Legation Lisbon, 11 July 1975.

55 SADFAP 1-22-3 Vol. 5 Angola Relations with S.A., 5.3.75. to 25.7.75, Discussion with High Commissioner Cardoso, 16 April 1975.

56 See attachment to Doc. 113, Minutes of a National Security Council Meeting, 27 June 1975, in Foreign Relations of the United States, 1969-1976, vol. xxviII, Southern Africa.

57 On South Africa, in particular, Robin Hallett, 'The South African Intervention in Angola, 1976', African Affairs, 77.308 (July 1978), 347-86; Deon Geldenhuys, The Diplomacy of Isolation: South African Foreign Policy Making (New York: St. Martin's Press, 1984), pp. 75-84; Dan O'Meara, Forty Lost Years, pp. 209-29; James P. Barber and John Barratt, South Africa's Foreign Policy: The Search for Status and Security, 1945-1988 (Cambridge: Cambridge University Press, 1990), pp. 186-96. See also John A. Marcum, 'Lessons of Angola', Foreign Affairs, 54.3 (1976), 407-25. More recent accounts of value include Edward George, The Cuban Intervention in Angola, 1965-1991: From Che Guevara to Cuito Cuanavale (London: Frank Cass, 2005), pp. 49-115 and P. Gleijeses, Conflicting Missions: Havana, Washington, Pretoria (Alberton, South Africa: Galago, 2002), pp. 230-347. On the role of the United States, Thomas J. Noer, 'International Credibility and Political Survival: The Ford Administration's Intervention in Angola', Presidential Studies Quarterly, 23.4 (1993), 771-85, provides a useful summation of the literature. Important memoirs include Henry Kissinger, Years of Renewal (New York: Simon \& Schuster, 1999); John Stockwell, In Search of Enemies: A CIA Story (New York: Norton, 1978); and Magnus Malan, My Life with the SADF (Pretoria: Protea, 2006). Two works, sympathetic to the SADF, essential for the military aspects are S. du Preez, Avontuur in Angola: Die Verhaal van Suid-Afrika 
The standard narrative is straightforward, but somewhat misleading. South Africa appears to have done little in Angola until August 1975, when workers involved in construction of the Calueque Dam complex on Cunene River, about $20 \mathrm{~km}$ from the Namibian frontier, came under threat from some or all of the liberation movements, as Portuguese power in Angola drained away. This led to a small force of SADF troops occupying the complex. Then, in the middle of October, South African forces moved northwards, supposedly in hot pursuit of guerrillas, but in reality to prevent the Soviet and MFA-backed MPLA from coming to power. Considerable debate has raged over whether or not this was done with the blessing of the United States. Days before 11 November 1975, the date set at the Alvor talks for Angolan independence, the South Africans were close to Luanda but chose, puzzlingly, not to attempt to seize it, although they did aid, with air and artillery support, the disastrous FNLA offensive on Luanda from the north, which was broken up by a small force of Cuban and MPLA troops. Cuba, alarmed by the South African advance, soon went from deploying a relatively modest number of advisers to the MPLA to rushing tens of thousands of front-line soldiers into Angola. With the United States unwilling to provide much practical or moral cover after Congress had banned all financial aid to Angola, overt or covert, through the Clark Amendment of 19 December 1975, the SADF began a withdrawal southwards in mid-December 1975, shadowed all the way by the Cubans and the MPLA. By March 1976, the SADF had left Angola. Of its allies, the FNLA had been broken and the União Nacional para a Independência Total de Angola (UNITA) relegated to a guerrilla force. To its supporters, the SADF, betrayed by a decadent United States suffering from a Vietnam syndrome, remained undefeated. To its detractors, however, it had narrowly avoided a military catastrophe at the hands of a superior Cuban expeditionary force.

\section{South African Decision-Making}

How did it all go so wrong for Pretoria? According to one account, South Africa appears to have considered encouraging the development of irredentism among the major tribal grouping in southern Angola and Northern Namibia, perhaps creating a Great Ovambo state that would act as a buffer between it and the South West Africa People's Organization (SWAPO), which stepped up its activities in the face of the vacuum left behind by the Portuguese. Such a move was greatly feared by all three Angolan liberation movements. ${ }^{58}$ Nevertheless, South African officials met with representatives of the three major liberation movements seeking concrete assurances that they would respect the border

se Soldate in Angola, 1975-1976 (Pretoria: Van Schaik, 1989) and F. J. du T. Spies, Operasie Savannah: Angola 1975-1976 (Pretoria: SADF Directorate of Public Relations, 1989).

${ }^{58}$ Hallett, 'The South African Intervention in Angola, 1976', pp. 351-52. 
and by implication not support the developing SWAPO campaign. ${ }^{59}$ The Financial Times, indeed, claimed that the MPLA had reportedly acquiesced in this demand. In July 1975, a South African general, D. R. Marais, was quoted as claiming that two to three thousand SWAPO cadres were being trained in southern Angola, although this claim was swiftly debunked by another senior officer. However, SWAPO attacks led to South African cross-border incursions into Angola, which apparently involved the SADF in clashes with SWAPO, MPLA and UNITA forces. ${ }^{60}$ Meanwhile, in April 1975, the South African government had asked the Portuguese High Commissioner to Angola to take action to protect the workers involved in the construction of the abovementioned Calueque Dam on the Cunene River. In May 1975, an alarmist SADF report advocated increased support for the FNLA and UNITA to forestall the MPLA. After the failure of Portuguese authorities to take action, the SADF deployed a platoon which seized control of the complex. ${ }^{61}$

However, sometime in the autumn of 1975, Pretoria decided to become more deeply involved in the developing Angolan conflict. It is usually assumed that the Angolan intervention was primarily driven by P. W. Botha and the SADF, since it ran contrary to the détente strategy favoured by the Department of Foreign Affairs and General van den Bergh's BOSS, which appeared to have paid off in Mozambique. Crucially, then, the intervention in Angola fitted into a wider context of inter-departmental turf wars within the South African security and diplomatic establishment for control of foreign and defence policy. Escheel Rhoodie, Secretary of the Department of Information, later sacked in disgrace for his role in the Information Scandal ('Muldergate'), was in the 1970s a close ally of Van den Bergh. Rhoodie claims that in August 1975, without the approval of Vorster or the Cabinet, P. W. Botha sent South African troops to guard the Calueque hydro-electric plant and that this developed into a hotpursuit operation against guerrilla groups that extended nearly to Luanda by November 1975. In this version, the invasion's 'pursue-to-Luanda' strategy became a fait accompli. ${ }^{62}$ Somewhat in support of this, Deon Geldenhuys suggests that a lethargic John Vorster was consulted by Botha but had little input into the military campaign, which appears to have been ad hoc and opportunistic rather than working to any overarching strategy. ${ }^{63}$ The Defence establishment was able to elbow the Department of Foreign Affairs aside over Angola under Vorster's rather 'unstructured decision-making'. ${ }_{4}$ However, Jamie Miller, citing a range of South African sources and interviews, suggests a

59 Spies, Operasie Savannah, pp. 60-65.

60 Hallett, 'The South African Intervention in Angola, 1976', pp. 351-52.

61 According to the account given by P. W. Botha to the House of Assembly, 26 January 1976, Hansard 1 Cols $44-52$.

62 See Eschel M. Rhoodie, P. W. Botha: The Last Betrayal (Melville: S. A. Politics, 1989), pp. 194-96. Apart from Rhoodie, the Muldergate scandal also claimed the careers of John Vorster (by then State President) and Connie Mulder, the Minister for Information (who was heir apparent to Vorster).

63 Geldenhuys, The Diplomacy of Isolation, pp. 75-84; O’Meara, Forty Lost Years, pp. 220-21.

64 Geldenhuys, The Diplomacy of Isolation, p. 82. 
gradual escalation of South African involvement beginning with arms, border crossings, training and eventual intervention, with Botha and SADF leading the charge over the heads of BOSS and the Ministry of Foreign Affairs. ${ }^{65}$

The Portuguese initially complained about this Calueque occupation, although their inability to protect the facility meant that they were forced to tolerate it. Still, they requested that South Africa do everything possible to avoid any direct confrontations. ${ }^{, 66}$ It would appear that the SADF began to engage MPLA forces at this time and the Lisbon press, notably the communistleaning Diário de Notícias, suggested that a full-scale South African invasion was underway, which the Embassy in Lisbon denied. ${ }^{67}$ In September, Portuguese officials met a senior South African officer, General Armstrong, to discuss the situation in southern Angola. They were happy to allow the SADF to occupy the dam but believed that control should be ceded to the MPLA in due course. They brought with them a message that the MPLA wanted normal relations with South Africa and would honour the contract for the dam. The Portuguese emphasized that the MPLA was the only party that really counted and that it had more 'brains' than the others, as it commanded the allegiance of all the black professional class. ${ }^{68}$ At this stage the scope of the South African intervention remained limited and arguably defensible. The country's military was protecting an important asset, into which South African resources had been poured, in the absence of the Portuguese, who were no longer capable of doing so. In truth, South Africa no longer cared about Portuguese sensibilities. In a contemptuous report, drafted in August 1975, the military attaché in Lisbon concluded,

The importance of Portugal is over-estimated. If Angola is handed to the MPLA, which is expected shortly, the communist [sic] would be celebrating a big victory since such a move would be irrevocable. The communists in Portugal are at the moment holding on until the UDI for Angola is established, after which, Portugal may go either way, being of no real importance anyway. The goals of the Communists were Mozambique and Angola and not Portugal. Mozambique irrevocable [sic] an established communist state and Angola well on its way. ${ }^{69}$

At this stage, the Department of Foreign Affairs and BOSS remained firmly opposed to military intervention, as was notable from an inter-departmental

65 See Jamie Miller 'Yes, Minister: Reassessing South Africa's Intervention in the Angolan Civil War, 1975', Journal of Cold War Studies, forthcoming, passim. The authors are grateful to Jamie Miller for an advance copy.

66 SADFAP 1-122-3 Vol. 6 Angola Relations with SA, 26.7.75 to 13.11.75, Brand Fourie, Secretary Department of Foreign Affairs to Admiral Biermann, Chief of SADF, 21 August 1975.

${ }_{67}$ SADFAP 1-122-3 Vol. 6 Angola Relations with SA, 26.7.75 to 13.11.75, Ambassador Lisbon to Secretary for Foreign Affairs, Pretoria, 3 September 1975.

68 SADFAP 1-122-3 Vol. 6 Angola Relations with SA, 26.7.75 to 13.11.75, Memo on Relations with Angola, 24 September 1975 .

${ }_{69}$ SANDFAP HSI AMI Groep 3 Houer 461, MI/LIA/1/ 1/4 Military Attaché Lisbon to Chief of Staff Intelligence, 'Portugal: Forecast with Reference to Angola', 18 August 1975. 
meeting on 11 August 1975. Botha had received authorization from Vorster but remarkably neither Fourie nor Van den Berg was consulted for their view. ${ }^{70}$ The occupation of the dam hardly constituted a major intervention but the very fact that the SADF were occupying a part of Angola brought Pretoria into the maelstrom of a post-colonial state in a process of disintegration. The Defence Forces' willingness to recruit ex-DGS agents and their private army, the fearsome Flechas, to bolster the anti-MPLA force being assembled in the south of Angola reflects this. It was also clear that the MPLA was going to win unless sufficient Western or South African aid could be brought to bear in support of its rival factions.

Sometime in the late autumn of 1975 , the various competing blocs in the South African governmental apparatus began to coalesce around an interventionist strategy. Firstly, after initially not being especially discriminating about the liberation movements of Angola, South African officials had begun to make contact with both Jonas Savimbi's UNITA and Holden Roberto's FNLA. There are reports that General van den Bergh, the head of BOSS, had met the MPLA dissident leader, Daniel Chipenda, for three days of talks at Windhoek, in July $1975 .^{71}$ International circumstances certainly seemed to be pushing South Africa towards bolder action. The Mobutu regime in Kinshasa and President Kaunda in Lusaka, important partners in Vorster's proposed détente, were increasingly concerned about the MPLA coming to power. Moreover, US Secretary of State Henry Kissinger, alerted to the situation by Kaunda, had become increasingly committed to frustrating the MPLA's intentions. Convinced that this was a test of America's mettle after the recent fall of South Vietnam to the North Vietnamese, Kissinger rejected the advice to stay on the sidelines offered by both the State Department and the CIA, relatively sanguine about the possibility of the MPLA winning. However, the US decision to step up covert aid to the FNLA appears to have had a dual effect. On the one hand, it led to increased Soviet and Cuban support for the MPLA; on the other, it convinced South Africa that a successful intervention might rekindle relations with the United States. Again according to Rhoodie, General van den Bergh, after meeting with Holden Roberto, probably in October 1975 at Mobutu's palace in Kinshasa, told the South African cabinet that the CIA would support a pincer attack on Luanda by the FNLA from the north, and by South Africa and Jonas Savimbi's UNITA from the south. ${ }^{72}$ This meeting tallies, chronologically at least, with the expansion of the South African military mission from defending Calueque to attempting to frustrate the MPLA's coming to power. It also suggests that

70 SADFAP 1-22-3 Vol. 6 Angola Relations with SA, July to November 1975, Meeting on Calueque Dam, 11 August 1975.

${ }_{71}$ Hallett, 'The South African Intervention in Angola, 1976', p. 354.

72 This is according to Eschel Rhoodie, quoted in Mervyn Rees and Chris Day, Muldergate: The Story of the Info Scandal (Johannesburg: Macmillan, 1980), p. 195. The CIA, as late as June 1975, according to DCI William Colby, was unwilling to get involved with the South Africans. See Doc 113, 'Minutes of a National Security Council Meeting', 27 June 1975, in FRUS, 1969-1976, vol. xxviII, Southern Africa. 
the invasion, rather than being simply a Botha-directed solo run, in fact had wide support from among South Africa's most significant senior ministers. General Magnus Malan, the chief of the South African army, reports that a government order was given to launch 'Operation Savannah' on 15 October. The objectives were somewhat open to interpretation: to protect the interests of South Africa and SWA, to aid the FNLA and UNITA, and promote détente in southern Africa. There was no explicit 'march-on-Luanda' instruction given. ${ }^{73}$ It would also appear that the intervention was to be highly secret, so as to spare the blushes of UNITA/FNLA and those African states which wished to see the MPLA stopped. There was also the problem that South Africa's laws banned the deployment of the SADF national servicemen outside the country's borders. ${ }^{74}$ Soldiers were initially uniformed as mercenaries.

Declassified South African documents give no definitive rationale about the decision-making behind Pretoria's intervention. If, as seems likely, it was opportunistic, haphazardly organized, and had no clear grand strategy behind it, then maybe no documentary rationale is extant. The British Ambassador to South Africa nevertheless attempted to summarize, post facto, Vorster's aims:

a) to prevent MPLA from acceding to power in Luanda or, conversely, of giving UNITA and FNLA a chance of taking a major share in government as successors to the Portuguese;

b) to prevent any further supply of Russian weapons to MPLA by seizing the main entry port for these supplies in Luanda;

c) if objective (a) failed, to help UNITA establish control over the Benguela Railway and so re-open it for use by Zaire and Zambia, two countries with which South Africa was trying to establish a position of influence as part of the détente policy;

d) in the process to eliminate SWAPO bases in southern Angola.

This diplomat added, 'the South African Government must have hoped to achieve these results quickly, and secretly, in close collaboration with Dr Savimbi of UNITA and with some tacit, but for obvious reasons unacknowledged, support from Zaire and Zambia. ${ }^{75}$

\section{The American Link}

South Africa was motivated by opportunism: its initial thrusts with relatively tiny forces brought great rewards as the MPLA's military wing, the FAPLA, was rapidly swept aside and the SADF was, at one stage, a mere hundred miles from Luanda. However, its Achilles heel was that it depended on the small and well-trained SADF force not running into anything more formidable than inexperienced FAPLA troops. Should the SADF encounter anything stronger,

73 Malan, My Life with the SADF, p. 118.

74 See Hilton Hamann, Days of the Generals (Cape Town: Zebra, 2001), pp. 32-33.

75 The National Archives UK, Kew, London (TNAUKKL), Foreign and Commonwealth Office, 51-425, Cape Town to James Callaghan, 9 February 1976, 'South Africa and Angola - The Penalties of Intervention'. 
like Cuban or Soviet personnel, Pretoria hoped it might rely on the support of the United States. While Western and South African propaganda suggested that the Cuban intervention was merely a proxy for the Soviet Union, most recent writing on the event, based on Cuban archives and accounts, suggests that the massive deployment of Cuban forces after November 1975 was motivated by Cuba's own desire to save a sympathetic regime (MPLA) from total defeat. In reality, South Africa's intervention was catastrophic on every level. Militarily it failed to achieve its objective of capturing Luanda. Sufficient numbers of Cuban troops stiffened the MPLA, which allowed them to rout an FNLA offensive on 9 November. $^{76}$ The idea of a pincer movement on Luanda by the FNLA, UNITA and the SADF, which had so excited General van den Bergh in Kinshasa, was now a dead letter. The SADF contingent, which might have been sufficient to take care of the MPLA on its own, now faced the danger of a rapidly growing Cuban military force armed with heavy weapons, particularly artillery - the terrifying 'Stalin's Organs' rocket launchers - that outranged the World War II-vintage guns of the South Africans. In any case South Africa, according to Malan, had decided to stay in Angola either until 11 November (Independence Day) or the OAU meeting which was to decide the key question of which competing Angola government to recognize. However, it was not until the end of the year that a final decision to pull back was made and this was chiefly motivated by developments in the United States.

Washington turned out to be an unreliable ally. It was now paralysed as President Ford and Secretary Kissinger found that their ability to support South Africa was compromised by a general unwillingness to be too closely associated with Apartheid. However, they did not want South Africa to pull out of Angola, as a conversation between senior Administration officials on 21 November 1975 reveals:

William Colby (Director, CIA): [South Africa would] like to get their troops out, and hire mercenaries. They say that they don't have the money to do this and have turned to us. I think that this is political dynamite. The press would be after us. They and Africans would say that the MPLA is supported by the big, brave Russians, while the others are backed by the bad South Africans and Americans. That would be unpleasant.

Joseph Sisco (State Department): More than that. Your description is too mild. [...] I do not favor giving any support to the South Africans. [...] We would not want to discourage them, but leave them to their own devices.

Brent Scowcroft (National Security Council): We do not want to discourage them. ${ }^{77}$

76 South African artillery was airlifted especially for this purpose and took part in the battle, but could do little to stop the rout. This has been often described. An official South African perspective can be found in Malan, My Life with the SADF, pp. 124-26.

77 FRUS, 1969-1976, vol. XxviII, Southern Africa, Doc. 139, 'Memorandum for the Record', Washington, November 21, 1975, 40 Committee Meeting. 
The extent of the assurances the United States gave South Africa and how much they encouraged its intervention remains unclear and has not really been cleared up by the recent release of the relevant Foreign Relations of the United States volume on southern Africa between 1969 and $1976 .^{78}$ Donald Easum, the former Assistant Secretary of State for African Affairs, who was disliked and ignored (like much of the State Department) by Henry Kissinger for being overly sympathetic to black Africa, was of the view that the Secretary of State had used 'back-channel' business contacts to encourage P. W. Botha to intervene in Angola, probably in October. ${ }^{79}$ This should be contrasted with Kissinger's own account - 'South Africa had opted for intervention without prior consultation with the United States' - a view surprisingly endorsed by John Stockwell, a dissident CIA officer, in his hostile account of the American intervention in Angola. ${ }^{80}$

The South African Ambassador in Washington, R. F. 'Pik' Botha, was well aware that the Ford administration was torn between wishing to stop the Soviets and Cubans winning while simultaneously wishing to remain distant from South Africa, in the face of a growing backlash in Congress. However, his understanding of events in Angola was mainly shaped by watching the fighting on the US networks, as he appears to have been given little information about what was going on from Pretoria. Domestically, South African intervention was blanketed in extraordinary secrecy, with no reports on radio or in the newspapers. Eventually Pik Botha was informed by Foreign Minister Hilgard Muller that the SADF mission had support at the highest levels in Washington. Pik Botha demurred, warning nevertheless that an imminent Senate vote would cut off funding. ${ }^{81}$ When he informed Vorster of this, the Prime Minister refused to believe him. Muller told the US Ambassador on 15 December 1975 that the South African view, based on their information, was that, psychologically speaking, the ideal moment for the US and the Western Powers to

78 FRUS, 1969-1976, vol. xxviII, Southern Africa, passim.

79 The Foreign Affairs Oral History Collection of the Association for Diplomatic Studies and Training, interview with Donald B. Easum, Published 17 January 1990, Library of Congress, Manuscript Division, Washington, DC 20540 USA, Digital ID mfdip 2004easo1 <http://hdl.loc.gov/loc.mss/ mfdip.2004easo1>: 'In fact, there's been a lot of suspicion all along the line that he had friends and connections, and that he permitted certain information to flow independently of official State Department channels to Vorster. I don't know this for a fact, but when the South Africans invaded Angola massively in what I think was called the Proteus invasion in October of 1975, there are many people who believe that he let - was it then Botha? He let Botha know through business contacts, or whatever, that Botha would be supported if he did that. And when Botha didn't get that kind of US military support, Botha was downcast, and said he'd been betrayed by the Americans. And many of us think that Kissinger, for whatever reason, couldn't follow through on pledges he had made.'

80 Henry Kissinger, Years of Renewal, p. 821, John Stockwell, In Search of Enemies, p. 186. However, Stockwell accused the CIA of cooperation with the South Africans, passim. Kissinger seemed to suggest the CIA as one of the major sources of leaks that holed the entire operation below the waterline. See Kissinger, Years of Renewal, p. 827.

81 See the extensive excerpts from an interview with R. F. Botha in South African Democracy Education Trust, The Road to Democracy in South Africa, Volume 2 [1970-1980] (Pretoria: Unisa Press, University of South Africa, 2007), pp. 65-68. 
apply 'maximum pressure' had arrived. ${ }^{82}$ A couple of days prior to this, Edward W. Mulcahy, the acting Assistant Secretary of State for African Affairs, had specifically claimed that the US administration had support in the Senate, and even the House of Representatives, to continue aid. Indeed Mulcahy informed the South Africans that he had gone out of his way to give a sympathetic rendering of South Africa's case over Namibia and Pretoria's other problems to Senator Dick Clark, who, according to the Embassy, had found it 'very interesting and even remarkable. ${ }^{83}$ However, Congress was opposed to any possibility of being sucked into the southern African conflict, particularly as it was clear that much of the administration - most notably CIA Director William Colby - saw little difference between the Angolan factions, and on 19 December 1975 the Clark Amendment stopped all US aid to FNLA and UNITA, so destroying the credibility of those in the South African government who had claimed to have US backing. ${ }^{84}$ As an American official ruefully noted: 'The key to keeping our side in Angola from collapsing is So. Africa. As far as Africans are concerned they would agree to have So. Africa clean up Angola, but we couldn't pay the domestic price in this country. ${ }^{85}$

When the Clark Amendment was passed, Pik Botha was recalled for consultations at Vorster's Eastern Cape holiday home, along with other senior ministers and advisers. They met on New Year's Eve 1975 to discuss strategy in the light of the new developments, which included the withdrawal of US support and the capture of a small number of SADF troops. No official account of this meeting has surfaced. Pik Botha, in any case, found that the Chief of the South African Army, Magnus Malan, was now the chief proponent of an orderly withdrawal as there was 'a danger of encirclements and major battles.' The consensus of the meeting was that withdrawal had to begin. ${ }^{86}$ Politically, the intervention had failed, since its very occurrence had gravely discredited Pretoria's Angolan allies, the FNLA and UNITA. African countries that had sat on the fence regarding recognition of the MPLA, such as Nigeria, Algeria, Ethiopia, Tanzania, the Sudan and Ghana, all ended up recognizing the MPLA government when the extent of South African intervention became clear. The OAU condemned the intervention. Furthermore, the support of the United States proved transient as Congress cut off supplies and money to the FNLA and UNITA; Vorster, P. W. Botha, and Nationalist Party MPs all expressed

82 SADFAP 1-22-3 Vol. 7 Angola Relations with SA 24.10.75 to 31.12.75, Secretary for Foreign Affairs, Pretoria to SA Embassy Washington, 15 December 1975.

${ }^{83}$ SADFA 1-22-3 Vol. 7 Angola Relations with SA 24.10.75 to 31.12.75, SA Embassy Washington to Secretary for Foreign Affairs, 12 December 1975.

${ }_{84}$ Thomas J. Noer, 'International Credibility and Political Survival', p. 778.

85 FRUS, 1969-1976, vol. xxviII, Southern Africa, Doc. 156, 'Memorandum of Conversation', Washington, 19 December 1975, note 5 for deputy Secretary of State, Ingersoll's note.

${ }^{86}$ See Malan, My Life with the SADF, pp. 130-31, whose account tallies with Pik Botha's in The Road to Democracy in South Africa, Volume 2, pp. 65-68. 
great bitterness about this betrayal in the South African Parliament. ${ }^{87}$ Lastly, it was made clear, as South Africa prepared to confront the Cubans, that the United States could not openly support the apartheid regime. Faced with international isolation and potential military disaster, the South Africans retreated before a major confrontation with the Cuban expeditionary force could develop. In the early weeks of 1976, with the SADF in full retreat, the Cubans and the MPLA captured all the major towns of central and southern Angola, though they behaved with circumspection and did not attempt to engage the South Africans. ${ }^{88}$ Neither did they attempt to push into South West Africa. In early March, through the mediation efforts of the British, the Soviets and the Nigerians, the South Africans received assurances that the Calueque dam would be respected. ${ }^{89}$ In the end, South Africa's withdrawal was only temporary and it found itself dragged into a border war that would rage until the end of the 1980 os on the Namibian-South African frontier..$^{\circ}$ More importantly, however, the perception of the defeat of the invincible South African military machine contributed to an uprising in the townships, beginning with Soweto in 1976, that would rage until the end of Apartheid in the 199os.

\section{Conclusion}

Portugal's hurried (and, in the Angolan case, opaque) decolonization in 1974-75, and South Africa's inept response, represented an existential threat to the Apartheid regime, but its leaders did not yet realize this. The nearest thing to a post-mortem we have on the Angolan debacle is a report for the liaison committee of senior South African and Rhodesian military officers, which appears to have replicated at least some of the old functions of Exercise ALCORA..$^{11}$ The aim of the report was to reassess the threat to the two remaining white regimes in the aftermath of the new reality of 'direct intervention by a foreign power which had now been established'. ${ }^{22}$ With regard to Soviet objectives in southern Africa, it noted: 'There can be little doubt that the USSR would not have escalated the war in Angola had the USA and the Western World shown any determination to counter Soviet involvement.' Soviet objectives included the neutralization of South Africa's détente policy, 'which was proving an embarrassment to them', and gaining a foothold in Angola, to offset Western and Chinese influence in Africa, securing riches and

\footnotetext{
87 Hallett, 'The South African Intervention in Angola, 1976', p. 383.

88 Ibid.

89 Botha in The Road to Democracy in South Africa, Volume 2, p. 68.

90 See George, The Cuban Intervention in Angola, 1965-1991, and Gleijeses, Conflicting Missions: Havana, Washington, Pretoria.

91 SANDFAP, HIS AMI Groep 3 Houer 404, 'Minutes of discussions between delegations from Rhodesian Security Forces and SADF held in Pretoria during the period 26-27 February 1976'.

92 SANDFA, HIS AMI Groep 3 Houer 404, 'The Effect of the Developments in Angola on the Security Situations of Rhodesia and the RSA', paragraph 2.
} 
strategic raw materials in Angola, and expanding its maritime influence in the southern oceans. ${ }^{93}$ The USSR had virtually achieved its main objective in Angola and a period of consolidation could be expected. An escalation beyond the borders would put a strain on Soviet resources. The continued technical responsibility of Britain for Rhodesia and South Africa's control of South West Africa made a Soviet-backed conventional attack on either unlikely. The risk of a more conventional attack would be influenced by 'actions and reactions' of Rhodesian and South African forces and whether the Soviet objectives 'could be attained by merely continuing to support the revolutionary onslaught, which can be gradually stepped up should the situation become more favourable. ${ }^{94}$

The OAU remained committed to the Lusaka declaration and the 'total elimination of White Rule in southern Africa, the order of priority being Rhodesia, South-West Africa and finally the Republic of South Africa.'95 It was noted that the Defence Sub-Committee of the OAU Liberation Committee had adopted a report rejecting peaceful solutions to the Rhodesian crisis. Other rhetoric suggested an intensification of the armed struggle in 'Zimbabwe and Namibia'. The more militant members of the OAU had been 'buoyed up' by the successes in Mozambique and Angola. 'They', it was noted, 'have seen how "liberation" can be hastened by support from foreign external sources using heavy weapons. ${ }^{96}$ However, the report was of the view that 'at the moment there is no likelihood of a conventional war threat emanating from the OAU, or any of its components.' This did not mean it could not be reviewed should the 'terrorist' campaign fail or should Mozambique, for instance, claim that its territorial integrity was threatened: 'In this case the lesson of the Angolan civil war (the effectiveness of heavy weapons against lightly armed troops) may be applied and result in OAU countries sending military aid, or external forces (e.g. Cuban) may be 'invited to assist in the attainment of OAU aims.' Rhodesia would be most vulnerable to such an escalation. ${ }^{97}$ It was a grim prognosis, and one echoed in the minute of a British Foreign Office official, Peter Young:

Détente [in Southern Africa] is in ruins and, arguably, the threat to Namibia is now greater than it would have been if the MPLA had won sooner and South Africa had adopted the same attitude to them as they have done to FRELIMO. Certainly, there are now many more Cubans and a stronger Russian presence and influence which could threaten Namibia. But the important question is how all this will affect the Government's internal policies and life within the Republic. I agree [...] that the present government are unlikely now to act logically and adopt more liberal policies towards the majority. The Nationalists are much more likely to

93 Ibid, paragraph 5.

94 Ibid, paragraph 6.

95 Ibid, paragraph 8.

96 Ibid, paragraph 10.

97 Ibid, paragraphs 11-12. 
react the other way. But if Rhodesia fell violently and Mozambique became uncooperative, demands for change from the opposition may well compel Mr Vorster to alter course. Whatever happens, I think the historians will mark South Africa's Angolan venture as a significant turning point away from peaceful evolution. ${ }^{98}$

Research for this article was made possible by grants from the Instituto Camões, the British Academy, and the Irish Research Council for the Humanities and Social Sciences.

98 TNAUKKL, FCO, 51-425 P. M. H. Young Central and Southern African Department (FCO) to Mr Reid (FCO), 4 March 1976. 